Volume 4, Issue 1 (2020), pp. 45-49

International Journal of

Entrepreneurship and Economic Issues

ISSN: 2616-0048 Print/ ISSN: 2631-231X Online

\title{
Challenges of Online Education during COVID-19 Pandemic in Nepal
}

\author{
Kabita Khati \\ Padmakanya Multiple Campus, Nepal, \\ Khem Raj Bhatta \\ Central Department of Psychology, Nepal
}

\begin{abstract}
Covid-19 lead to colleges and universities ending in-person instruction. The online education that emerged after COVID-19, has been challenging in Nepal because students, teachers, and administrators were not prepared for it. Stakeholders of education should work in many areas to enhance the effectiveness of online education and make it more similar to classroom education.
\end{abstract}

Keywords: COVID-19, Online Education, Challenges, College Education

The coronavirus outbreak that started from Wuhan city of China in late 2019, has claimed more than four hundred thousand deaths globally. COVID-19 pandemic has become a threat to the community worldwide (Buheji et al., 2020) and Nepal is no exception. Nepal had the first case of COVID-19 on 20th February 2020 (Shrestha et al., 2020). In a span of three months, cases have been increased to 10728 and death toll to 24 (Mishra, 2020). 
Besides the casualties, the COVID-19 pandemic has a multidimensional impact globally and a large number of students are deprived of their education. The Pandemic contributed to closure of more than $90 \%$ of world's schools (Strauss, 2020). Many students in Nepal are experiencing distress due to the lockdown imposed immediately a week before their scheduled exams. Several students are still waiting for the exam schedule. Due to pandemic, those planning for abroad study are either waiting indefinitely or abandoned their plans (Dhungana, 2020). Educational institutes have, however, started online education as an emergency alternative to traditional face-to-face education. As lockdown completed three months government of Nepal and many Universities have formalized online classes.

Online classes are flexible for both teachers and students but such classes have their own challenges (Gillett-Swan, 2017). The attention of students and safety issues can be important challenges during online classes (Phuyal, 2020). Also, children from low-income working class cannot join the online class as they often do know have access to a computer of reliable Internet service (Ghimire, 2020; Ojha, 2020). Professors who mostly relied on in-person modalities found the shift to online teaching challenging (Subedi, 2020). Many academicians considered the decision to move quickly to online or virtual class as premature in face of limited infrastructure and training. Some experts also argue that online classes in the Nepalese context are against the spirit of equitable access to education as this deprived right to education of economically marginalized people. Recent coverage by ABC News showed that many students do not consider online classes as equivalent to classroom experiences (Binkley, 2020). Teachers, administrators, and parents have are also questioning the effectiveness of online education.

\section{MAIN ARUGMENT}

Even though all stakeholders of education have concerns regarding the effectiveness of online education in Nepal, they report it differently. Students have four main issues regarding online education. First, they find it difficult to adapt to technology. Students often struggle to post assignments and $\log$ on to classes. Second, some students consider online classes as less interactive. For example, one of our students said, "there is more of teacher talking and less of interaction." Third, poor Internet connectivity in many areas of Nepal makes it difficult for students to attend classes and post 
assignments. Fourth, the unavailability of computers poses a challenge in learning.

For teachers, the problem arises because they neither expected nor prepared for online classes. Learning technology is one challenge for teachers. Also, the lack of eye contact makes it difficult for them to understand whether or not students are getting their pace. For some teachers, their children at home often disturb synchronous class delivery.

Administrators have different problems during online classes. For school administration, the primary problem surrounds on payment of house rent and salary in light of obstruction in fee collection. School administrators do worry that COVID-19 will result in a higher dropout rate as poverty soars. At the university level, administrators often find it hard to make teachers available to engaging training to better prepare for online learning. Also, the lower rate of attendance is a burden to administrators.

Parents also have many concerns regarding online education. The overreliance of their children on the Internet during lockdown is one insecurity they have. One parent said, "I fear, my child can go out of my hands." Working parents have added burden due to lower safety standards at worksites. These parents report anxiety about bringing COVID-19 to their homes. Also, some parents have issues because they have no one to take care of children when they are at work.

Despite many challenges, online education has some benefits for students, administrators, and teachers. Some students loved online classes either because it is flexible or because they would miss traditional classes due to jobs. For some students, online classes are good because it saves travel time. For administrators, the engagement of a variety of experts can be one benefit of online education. Due to flexibility of time, administrators can engage experts who would be unavailable in face-to-face classes. This trend has now started with many university classes engaging foreign experts as guest lecturers. For teachers, the flexibility of time is one merit of the online class. Thus, handled effectively, online education can be long term supplementary to traditional classes.

\section{CONCLUSIONS AND IMPLICATIONS}

Online education, though it has its positives, is full of challenges at the moment in Nepal. Despite some flexibility and the only alternative at the moment, a continuation of it without the development of physical and human resource infrastructures can be ineffective. Poor network, the security of the Internet, and the possibility of Internet addiction can be other 
challenges. Consideration of online education as a short-term solution by teachers and administrators can contribute to lower motivation and the ultimate effectiveness of online classes.

To enhance the effectiveness of online education in Nepal, stakeholders should focus more on the improvement of infrastructures, to train teachers, and motivate students. According to the World Health Organization, COVID-19 extend for two- three years. Thus, online education can be one important knowledge-sharing platform. Also, the enhancement of online education can be helpful to continue teaching learning education in other natural calamities like that Nepal experienced in the 2015-earthquake. At the moment, online education should be considered complementary rather than an alternative to traditional classes. Stakeholders of education should also work for equitable education when they plan for online education.

\section{REFERENCES}

Binkley, C. (2020, May 5). Unimpressed by online classes, college students seek refunds. abc News, Retreived https://abcnews.go.com

Buheji, M., da Costa Cunha, K., Beka, G., Mavric, B., de Souza, Y. L., da Costa Silva, S. S., ... \& Yein, T. C. (2020). The extent of covid-19 pandemic socio-economic impact on global poverty. a global integrative multidisciplinary review. American Journal of Economics, 10(4), 213-224.

Dhungana, S. (2020, June 25). Covid-19 lockdown affects Nepali students planning to go abroad. The Kathmandu Post, Retrieved https://kathmandupost.com

Ghimire, B. (2020, May 28). Digital divide too wide for online classes to succeed in Nepal. The Kathmandu Post, Retrieved https://kathmandupost.com

Gillett-Swan, J. (2017). The challenges of online learning: Supporting and engaging the isolated learner. Journal of Learning Design, 10(1), 20-30.

Mishra, A. (2020, June 25). Bikalpa ma Suti Ko Mask. Kantipur, p. 2.

Ojha, A. (2020, June 9). Children from low-income working class families can't join online classes. The Kathmandu Post, Retrieved https://kathmandupost.com

Phuyal, K. (2020, April 10). Challenges of Virtual Class. Himalayan Times, Retrieved https://thehimalayantimes.com 
Shrestha, R., Shrestha, S., Khanal, P., \& KC, B. (2020). Nepal's First Case of COVID-19 and public health response. Journal of Travel Medicine, 27(3), taaa024.

Subedi, A. (2020, May 10). Guru karma in virtual times. The Kathmandu Post, Retrieved https://kathmandupost.com

Strauss, V. (2020, April 6). Schools of more than 90 percent of the world's students closed during this pandemic. This graphic shows how fast it happened. Washington Post, Retrieved https://www.washingtonpost.com/

KABITA KHATI, M.A., is a Senior Lecturer in Padmakanya Multiple campus, Psychology Department, Tribhuvan University. Her major research interests lie in the area of psychological welling, higher education research and women issues. Email: kabitaedu@gmail.com

KHEM RAJ BHATTA, M.A., is Lecturer in Central Department of Psychology, Tribhuvan University. His major interests lie in the area of academic achievement of students, test anxiety and elderly issues. Email: bhattakhem123@gmail.com 